\title{
Extra money for British science insufficient to reverse decline
}

\section{London}

NEXT year's increase of $£ 47$ million in the science budget over previous plans will provide little respite for British academic science. The increase, announced last week by Education Secretary Kenneth Baker following the Chancellor's Autumn statement, falls well short of the $£ 103$ million deemed necessary by the Advisory Board for the Research Councils (ABRC). Of the extra money, which will bring the total science budget to $£ 696$ million, $£ 28$ million will pay for agreed salary rises, $£ 6$ million will go to a directed programme of research into AIDS and $£ 8$ million to the Natural Environment Research Council (NERC) towards a replacement ship for the British Antarctic Survey. The planning figure for each of the following two years is now $£ 729$ million, an 11 per cent increase over this year's budget.

The ABRC will decide in the next few weeks how the money is to be divided among the research councils. Initial reaction to Baker's announcement vary. Science bodies deplore the increase as derisory, with the lobby group Save British Science claiming that after accounting for inflation and correcting the sterling exchange rates on international subscriptions, a net decrease of $£ 19$ million will result.

For the administrators in the research councils, the money will probably enable the books to be balanced, although highly rated research projects will continue to be shelved and no money will be available to reverse earlier decisions to cut back on areas of research.

In its annual advice to the Secretary of State, the ABRC recommended an increase in the science budget of $£ 32$ million for 'necessary underpinning', $£ 27$ million for the replacement of obsolete equipment and $£ 44$ million for the reshaping of the science base (Nature 328, 369; 1987). However, the recommendations built on previously submitted advice on reorganizing academic science, contained in the document $A$ Strategy for the Science Base (Nature 328, 280; 1987). There seems to be some confusion about whether the strategy advice was considered when finalizing the budget. On the one hand Baker stated that the extra money would give scope for a "worthwhile start in 198889 on the establishment of interdisciplinary research centres, as recommended by the ABRC and to which I attach great importance". However, he then said that the government would be giving further consideration "in the next few months" for the strategic reshaping of the science base, taking account of ABRC's strategy advice and subsequent consultations.
One of the first things the research councils will need to know is whether the ABRC will be able to confirm the $£ 12$ million of provisional allocations it made some months ago using its 'flexibility margin'. For the Science and Engineering Research Council (SERC), which receives more than 50 per cent of the total budget, there should be money available for it to meet its major commitments salaries, international subscriptions and the operation of its recently installed Cray computer.

The number of research programmes SERC will be able to support under the government's LINK scheme (which encourages collaboration between industry and universities), and whether Britain will be able to afford to subscribe to the European Synchrotron Radiation Facility, will be decided in December. Plans to establish interdisciplinary research centres will probably continue. A centre for superconductor research is being set up, and two to four new centres will be established next year depending on the precise allocation of funds between the research councils.

Eyebrows have been raised over the allocation of $£ 8$ million to NERC towards a replacement for the British Antarctic Survey's 30-year-old vessel John Briscoe. In its strategy document, ABRC suggested that NERC's oceanography programme, with its associated fleet of vessels, is an area of big science "which we think may call for review". According to Jeremy Bray, the opposition Labour Party's spokesman on science, "presumably the new ship is needed to buttress the government's 'Fortress Falklands' policy". Privately, NERC officials concede that political interest in the Antarctic could have played a role in the decision to replace the vessel.

The Autumn statement provided for an extra $£ 56$ million for the universities for the 1987 academic pay settlement. Baker says the money will be released "as soon as the government is satisfied that the universites have sufficiently improved their arrangement for staff appraisal, probation and promotion". A further $£ 61$ million is to be made available in 1988-89 and later, $£ 53$ million of which will be earmarked for 'targeted programmes' of restructuring, including additional money for early retirements, 'new blood' appointments; 'rationalization' of a number of disciplines and an initiative in manufacturing systems engineering. Polytechnics and colleges will receive an extra $£ 64.5$ million, with an additional $£ 9$ million to help pay for their pending transfer from local authority control.

\section{Flying cockroach walks to victory}

\section{Sydney}

THE winner of the world's first transcontinental solar-powered road race from Darwin to Adelaide in Australia crossed the finish line last week, days ahead of its closest rival. An odd assembly of 24 solar vehicles which had gathered from around the world started on a 3,004-km trek from the north coast through Australia's desert heart to Adelaide in the south. When Sunraycer - the General Motors entry that completed the course in five and a half days - crossed the finish line, some of the other entrants had yet to reach Alice Springs.

Sunraycer's dominance of the race was obvious within $10 \mathrm{~km}$ of the starting line. Shaped like a flattened teardrop, and called the "Flying Cockroach", it can sustain speeds around $110 \mathrm{~km} \mathrm{~h}^{-1}$. Its average speed over the course was $66.7 \mathrm{~km} \mathrm{~h}^{-1}$

High technology was the key to Sunraycer's success. The expertise in lowspeed aerodynamics provided by body

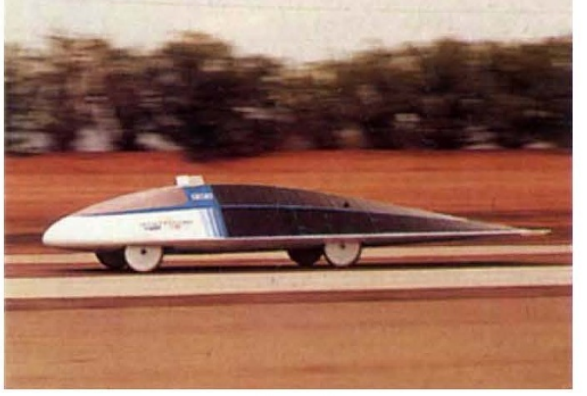

designer Paul McCready gave Sunraycer an extremely low drag coefficient as well as relative impunity to cross winds that caused headaches for other competitors. It used gallium-arsenide solar cells rather than the silicon cells used by the rest of the field. Sunraycer's 92 per cent efficient electric engine contained magnets made of an alloy of the rare earth neodymium. The alloy has an amorphous crystal structure, like that of glass, created by cooling the molten alloy so quickly that crystals have no time to form.

The energy may be free but the cars certainly are not: the Sunraycer cost between $\$ 3$ million and $\$ 15$ million.

The rules of the race limit each car to $8 \mathrm{~m}^{2}$ of solar cells. The cars race from 9 a.m. to 5 p.m. and park for the night at whatever point they have reached at that time. Cars which have reached Adelaide within 5 days of the winner are officially classified as having finished the race.

The third-place Swiss entry, Spirit of Biel, lost second position after a collision with a local motorist in Alice Springs. The police are to issue an infringement notice to the Swiss for failing to give way.

Charles Morgan 